\title{
Retrospective analysis of benign and premalign lesions in the oral cavity
}

\author{
Benign ve premalign oral kavite lezyonlarının retrospektif \\ analizi
}

\author{
Akif Gunes $^{1}$, Elif Karali ${ }^{1}$, Tugberk Sebit ${ }^{1}$ \\ ${ }^{1}$ Dept. of Otorhinolaryngology, Bolu Abant Izzet Baysal University, Faculty of Medicine, Bolu, Turkey
}

\begin{abstract}
Background The aim of this study was to retrospectively analyze the patients who were biopsied from the oral cavity and histopathologically diagnosed as benign and premalignant.

Methods In this study, we retrospectively examined histopathological diagnosis, sex and age groups of 67 patients who underwent incisional or excisional biopsy of the oral mucosa and diagnosed as benign or premalignant in the otorhinolaryngology clinic of a tertiary hospital between January 2014 and January 2019.

Results A total of 67 patients were included in our study, 33 (49.3\%) were male and 34 (50.7\%) were female. The mean age of the patients was $44.90 \pm 19.77$ years. According to age distribution, numbers of patients in 10-20, 21-30, 31-40, 41-50- 51-60, 61-70 and 71-80 age groups were 12 (17.9\%), 8 (11.9\%), 6 (9\%), 9 (13\%), 16 (23.9\%), 10 (14.9\%) and $6(9 \%)$, respectively. The most common benign lesions were pyogenic granuloma (10.4\%) and radicular cyst (11.4\%). Conclusions As a result, biopsies should be performed to exclude malignancy in the oral cavity. In addition, the diagnosis of rare lesions is important in terms of treatment management.
\end{abstract}

Key words: oral mucosa, oral cavity, biopsy, histopathological diagnosis

\section{O̊zet}

Amaç Bu çalışmada oral kaviteden biyopsi yapılan ve histopatolojik olarak benign ve premalign tanı koyulan hastaların retrospektif olarak ayrıntılı analizlerinin yapılması amaçlanmıştır.

Yöntem Çalışmamızda Ocak 2014-Ocak 2019 tarihleri arasında üçüncü basamak bir hastanenin kulak burun boğaz hastalıkları kliniğinde oral mukozadan insizyonel yada eksizyonel biyopsi yapılan ve histopatoloji tanısı benign yada premalign olarak değerlendirilen 67 hastanın retrospektif olarak histopatolojik tanı, cinsiyet ve yaş grupları dağılımları incelenmiştir.

Bulgular Çalışmamıza 33' ü (\%49.3) erkek, 34' ü (\%50.7) kadın olmak üzere toplam 67 hasta dâhil edildi. Hastaların yaş ortalaması $44.90 \pm 19.77$ olarak tespit edildi. Hastaların yaş dağılımları değerlendirildiğinde 10-20 yaş aralığında 12 (\%17.9), 21-30 yaş aralı̆̆ında 8 (\%11.9), 31-40 yaş aralığında 6 (\%9), 41-50 yaş aralığında 9 (\%13.4), 51-60 yaş aralığında 16 (23.9), 61-70 yaş aralığında 10 (\%14.9) ve 71-80 yaş aralığında 6 (\%9) hasta tespit edildi. En sık saptanan benign lezyonlar piyojenik granülom (\%10.4) ve radiküler kist (\%11.4) olarak tespit edildi.

Corresponding author: Akif Gunes, Dept. of Otorhinolaryngology, Bolu Abant Izzet Baysal University, Faculty of Medicine, Bolu, Turkey, Phone: +905062534948, E-mail: akif_gunes@hotmail.com

Received: 12 June 2019 Accepted: 18 June 2019

Conflicts of Interest: None

Funding: None 
Sonuç Sonuç olarak özellikle oral kavitede maligniteyi ekarte etmek için biyopsiler yapılmalıdır. Ayrıca nadir lezyonların teşhisi, tedavi yönetimi açısından önemlidir.

\section{Anahtar kelimeler: oral mukoza, oral kavite, biyopsi, histopatolojik tanı}

\section{Introduction}

Oral cavity is composed of gingiva, retromolar region, buccal and palatal mucosa, mouth base and lips. ${ }^{1,2}$ Pathological changes in the oral cavity tissues can be seen in different morphological and histopathological structures. Determining the right clinical diagnosis can sometimes be difficult. Many systemic diseases may lead to similar lesions in the oral cavity. ${ }^{2}$ Factors causing changes in the oral mucosa include infections caused by bacteria, fungi, viruses, parasites and other agents; physical and thermal injuries, changes in the immune system, systemic diseases, neoplasms, trauma and aging., ${ }^{3}$ In particular, long-term habits such as smoking tobacco or alcohol may cause precancerous or cancerous lesions. ${ }^{5}$

Oral mucosal lesions may be painful or painless. In addition, ulceration and indurated areas are common. Painful and ulcerated lesions may indicate the need for detailed evaluation of malignancy. ${ }^{1}$ Appropriate treatment in oral cavity lesions begins with correct diagnosis. The definitive diagnosis of oral cavity lesions can be established by histopathological examination and the gold standard is the diagnostic method. ${ }^{2}$ Irritation fibroma, giant cell fibroma, pyogenic granuloma, mucocel, lipoma, chronic inflammation, oral lichen planus are mainly benign lesions. Squamous cell carcinoma and basal cell carcinoma are the most common malignant diseases. Retrospective studies to assess the distribution of oral mucosal lesions are useful and important to assist in predicting the prevalence of a disease in the population and thus in identifying the high-risk subpopulation and in preventive and curative services. ${ }^{1}$

The biopsy shows the histopathological features of any lesion and is necessary for a definitive diagnosis. Detection of malignant or premalignant lesions in biopsy materials is also important for prognosis. Biopsies from lesions may also facilitate the identification of treatment strategies. It may contribute to the evaluation of the effectiveness of treatment. ${ }^{6}$

In this study, we aimed to retrospectively analyze the patients who were biopsied from the oral cavity and histopathologically diagnosed as benign and premalignant.

\section{Methods}

For this study, first of all, necessary permissions were obtained from the local ethics committee of our hospital.

In our study, a retrospective analysis of the patients who admitted with a complaint of swelling or pain in the otorhinolaryngology outpatient clinic of a tertiary hospital was performed and the patients who had pathology in the oral cavity and who had incisional or excisional biopsy were performed. Sixty-seven patients with histopathological benign or premalignant diagnosis were included in our study between January 2014 and January 2019 for oral cavity biopsy. Patients diagnosed with malignancy were not included in the study. Patients included in the study were evaluated according to the diagnosis, gender and age groups.

SPSS 21.0 was used for statistical analysis in this study. Descriptive statistical methods (mean, standard deviation, frequency and percentage distributions) were used to evaluate the data.

\section{Results}

A total of 67 patients were included in our study, 33 (49.3\%) male and $34(50.7 \%)$ female. The mean age of the patients was $44.90 \pm 19.77$ (min: 10 , max: 80) When the age distribution of the patients were evaluated, 12 were (17.9\%) in the 10-20 age range, 8 (11.9\%) were in the 21-30 age range, $6(9 \%)$ were in the $31-40$ age range, 9 (13.4\%) were in the 41-50 age group, 16 (23.9\%) were in the 51-60 age group, 10 (14.9\%) were in the 61-70 age group, and 6 (9\%) were in the 71-80 age group (Table 1).

In the evaluation, the dentigerous cyst 3, epithelial dysplasia 1, epithelial hyperplasia 3, epithelial inclusion cyst 2, epulis fissuratum 3, fibroepithelial papilloma 4, fibroepithelial polyp 2, granulation tissue 3 , pyogenic 
granuloma 7 , irritation fibroma 4 , cavernous hemangioma 3, chronic actinic chelitis 1, chronic inflammation 7, lymphangioma circumscriptum 1 , lichen planus 4 , leukoplakia 1, monomorphic adenoma (basal cell adenoma) 1 , mucocele 3 , odontogenic keratocyst 1 , radicular cyst 8 and squamous papilloma 5 were detected in patients. In addition, histopathological diagnoses of the patients according to age groups were given in Table 2 .

Table 1. Distribution of age groups

\begin{tabular}{lcc} 
Age group & Number & Percentage (\%) \\
10-20 years & 12 & 17.9 \\
21-30 years & 8 & 11.9 \\
31-40 years & 6 & 9.0 \\
41-50 years & 9 & 13.4 \\
51-60 years & 16 & 23.9 \\
61-70 years & 10 & 14.9 \\
71-80 years & 6 & 9.0 \\
Total & 67 & 100 \\
\hline
\end{tabular}

\section{Discussion}

The prevalence of oral mucosal disease is higher in elderly patients than in younger patients. Studies have demonstrated the relationship between oral mucosal disorders and aging. ${ }^{7}$ In this study, the oral mucosal lesions were found to be high in 40-70 age group (52.2\%). In a different study, it was found that this age group was between 40 and 61 years of age. ${ }^{8}$

However, age is not the only factor associated with oral mucosal diseases. ${ }^{4}$ Most population-based studies focus on the oral mucosa disease, the incidence and prevalence of malign and premalign disease. However, few studies have examined general mucosal lesions or mu- cosal changes. For example, a study conducted in Sweden reported 60 different oral mucosal lesions. ${ }^{9}$ In a different study, they also reported all premalign and benign lesions found in the screening and approximately 50\% of the reported lesions were diagnosed with keratosis. ${ }^{10}$ Recording of all oral mucosal lesions detected during physical examination clearly leads to a high prevalence of oral mucosal disease. ${ }^{5}$

This retrospective study was performed to evaluate the histopathological analysis of the oral cavity lesions. A total of 67 oral cavity lesions were evaluated during the study. In one study, it was shown that oral cavity lesions were more common in women. ${ }^{2}$ However, there is no significant gender difference in this study. In this study, the oral mucosal lesions were found to be high in 40-70 age group (52.2\%). In a different study, it was found that this age group was between 40 and 61 years of age. ${ }^{8}$ In our study, pyogenic granuloma (10.4\%) and radicular cyst (11.4\%) were the most common lesions. In one study, the rate of pterygiic granulomas ranged from $5 \%$ to $19 \%$.,11 In our study, the number of patients diagnosed with chronic inflammation was $10.4 \%$. In other studies this rate varies between $10 \%$ and $55 \% .^{12,13}$ In this study, the rate of hemangioma was $4.5 \%$. In other studies, the rates of oral cavity hemangioma vary between $11 \%$ and $30 \% .^{12,14}$ Another lesion in our study was squamous papilloma. The incidence of squamous papilloma was $7.5 \%$. In other studies, this rate was found to be between $2 \%$ and $11 \% .^{15-17}$ Epulis fissuratum which is formed due to prosthesis and trauma is most frequently seen after the 5 th decade., ${ }^{4,18}$ In this study, we determined it most frequently in 10-30 age range. This shows that the formation of epulis fissuratum is not only due to the use of prosthetic teeth, but it may also occur after any trauma to the oral mucosa.

Since our study was planned retrospectively, patients' informations could not be questioned in detail. Factors that could play a role in etiopathology such as smoking, alcohol use, and chronic irritation could not be questioned. This is the limitation of our study. 
Table 2. Histopathological diagnosis according to age groups

\begin{tabular}{|c|c|c|c|c|c|c|c|}
\hline Pathological diagnosis & $\begin{array}{l}10-20 \\
\text { years }\end{array}$ & $\begin{array}{l}21-30 \\
\text { years }\end{array}$ & $\begin{array}{l}31-40 \\
\text { years }\end{array}$ & $\begin{array}{l}41-50 \\
\text { years }\end{array}$ & $\begin{array}{l}51-60 \\
\text { years }\end{array}$ & $\begin{array}{l}61-70 \\
\text { years }\end{array}$ & $\begin{array}{l}71-80 \\
\text { years }\end{array}$ \\
\hline Dentigerous cyst & - & 1 & - & - & 1 & 1 & - \\
\hline Epithelial dysplasia & - & - & - & - & - & 1 & - \\
\hline Epithelial hyperplasia & 1 & - & - & 1 & - & - & 1 \\
\hline Epithelial inclusion cyst & - & 1 & - & - & 1 & - & - \\
\hline Epulis fissuratum & 1 & 2 & - & - & - & - & - \\
\hline Fibroepithelial papilloma & - & - & - & - & 3 & 1 & - \\
\hline Fibroepithelial polyp & - & - & - & - & 2 & - & - \\
\hline Granulation tissue & 1 & - & 1 & - & - & - & 1 \\
\hline Pyogenic granuloma & 1 & 1 & - & 1 & 1 & 1 & 2 \\
\hline Irritation fibroma & - & - & - & 1 & 2 & - & 1 \\
\hline Cavernous hemangioma & - & - & 1 & 1 & - & 1 & - \\
\hline Chronic actinic chelitis & - & - & - & - & - & - & 1 \\
\hline Chronic inflammation & - & - & 3 & 2 & 2 & - & - \\
\hline $\begin{array}{l}\text { Lymphangioma circum- } \\
\text { scriptum }\end{array}$ & - & - & - & - & - & 1 & - \\
\hline Lichen planus & - & 1 & - & - & 2 & 1 & - \\
\hline Leukoplakia & - & - & - & 1 & - & - & - \\
\hline $\begin{array}{l}\text { Monomorphic adenoma } \\
\text { (Basal cell adenoma) }\end{array}$ & 1 & - & - & - & - & - & - \\
\hline Mucocele & 1 & - & 1 & - & 1 & - & - \\
\hline Odontogenic keratocyst & - & - & - & 1 & - & - & - \\
\hline Radicular cyst & 4 & 1 & - & - & 1 & 2 & - \\
\hline Squamous papilloma & 2 & 1 & - & 1 & - & 1 & - \\
\hline
\end{tabular}




\section{Conclusion}

As a result, biopsies should be performed to exclude malignancy in the oral cavity. In addition, the diagnosis of rare lesions is important in terms of treatment management.

\section{References}

1. Modi D, Laishram RS, Sharma LDC, Debnath K. Pattern of oral cavity lesions in a tertiary care hospital in Manipur, India. J Med Soc 2013;27:199-201.

2. Fierro-Garibay C, Almendros-Marqués N, Berini-Aytés L, Gay-Escoda C. Prevalence of biopsied oral lesions in a Department of Oral Surgery. J Clin Exp Dent 2011;3:73-7.

3. Reichart PA. Oral mucosal lesions in a representative cross-sectional study of aging Germans. Community Dent Oral Epidemiol 2000;28:390-8.

4. Jainkittivong A, Aneksuk V, Langlais R. Oral mucosal conditions in elderly dental patients. Oral Dis 2002;8:218-23.

5. Campisi G, Margiotta V. Oral mucosal lesions and risk habits among men in an Italian study population. J Oral Pathol Med 2001;30:22-8.

6. Lin H, Corbet E, Lo E. Oral mucosal lesions in adult Chinese. J Dent Res 2001;80:1486-90.

7. Cebeci A, Gulsahi A, Kamburoglu K, Orhan B-K, Oztas B. Prevalence and distribution of oral mucosal lesions in an adult Turkish population. Med Oral Patol Oral Cir Bucal 2009;14:272-7.

8. Saraswathi T, Ranganathan K, Shanmugam S, et al. Prevalence of oral lesions in relation to habits: Cross-sectional study in South India. Indian J Dent Res 2006;17:121-4.

9. Axéll T. Occurrence of leukoplakia and some other oral white lesions among 20333 adult Swedish people. Community Dent Oral Epidemiol 1987;15:46-51.

10. Field E, Morrison T, Darling A, Parr T, Zakrzewska J. Oral mucosal screening as an integral part of routine dental care. Br Dent J 1995;179:262-7.

11. Riaz N, Warraich RA. Tumors and tumor like lesions of the orofacial region at Mayo Hospital, Lahore five year study. Annals of KEMU 2011;17:123-6.

12. Subhe N, Ali E, Hassawi BA. Tumors and tumor like lesions of the oral cavity a study of 303 cases. Tikrit Medical Journal 2010;1:177-83.

13. Mehta NV, Dave KK, Gonsai R, et al. Histopathological study of oral cavity lesions: A study on 100 cases. Int J Cur Res Rev 2013;5:110-5.

14. Pudasaini S, Baral R. Oral cavity lesions: A study of 21 cases. J Pathol Nep 2011;1:49-51.
15. Mujica V, Rivera H, Carrero M. Prevalence of oral soft tissue lesions in an elderly venezuelan population. Med Oral Patol Oral Cir Bucal 2008;13:270-4.

16. Al-Khateeb TH. Benign oral masses in a northern Jordanian population-a retrospective study. Open Dent J. 2009;3:147-51.

17. Misra V, Singh PA, Lal N, Agarwal P, Singh M. Changing pattern of oral cavity lesions and personal habits over a decade: hospital based record analysis from allahabad. Indian J Community Med 2009;34:321-6.

18. Nevalainen M, Närhi T, Ainamo A. Oral mucosal lesions and oral hygiene habits in the home-living elderly. J Oral Rehabil 1997;24:332-7. 